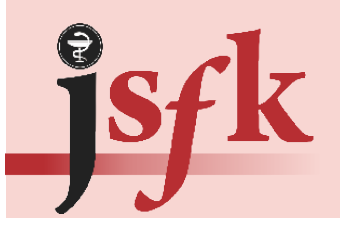

Jurnal Sains Farmasi \& Klinis (p- ISSN: 2407-7062 | e-ISSN: 2442-5435)

diterbitkan oleh Ikatan Apoteker Indonesia - Sumatera Barat homepage: http://jsfkonline.org

\title{
Isolasi dan Karakterisasi Senyawa Antibakteri dari Fraksi Etil Asetat Bakteri Bacillus sp.3 (A1) yang Bersimbiosis dengan Spon Laut Haliclona fascigera
}

(Isolation and characterization of antibacterial compounds of ethyl acetate fraction of bacteria Bacillus sp.3 (a1) that symbiotic with marine sponge Haliclona fascigera)

\author{
Rafky Putra, Friardi Ismed, Dian Handayani* \\ Fakultas Farmasi Universitas Andalas
}

\begin{abstract}
Keywords:
symbiotic bacteria;

Bacillus sp.;

antibacterial activity;

marine sponge;

Haliclona fascigera.

ABSTRACT: Bacillus sp. 3 is one of symbiotic bacteria of marine sponge Haliclona fascigera obtained from Mandeh Island, Pesisir Selatan, West Sumatra that can produce antibacterial compounds. This study aims to isolate the antibacterial compounds produced by Bacillus sp.3 (A1). The methods that has been used were bacterial cultivation on Nutrient Broth medium using Shaker Incubator at 150 RPM at $37{ }^{\circ} \mathrm{C}$ for 48 hours and isolation of antibacterial compound. The isolation method of the compound was carried out by column chromatography method. The testing of antibacterial activity was done by using agar diffusion method. Characterization of isolated compounds were performed using UV and IR spectrophotometer. From this research, two compounds RJ1 and RJ2 were obtained. The compound RJ1 was yellow oily $(2.8 \mathrm{mg})$. The compound RJ1 can inhibit Staphylococcus aureus ATCC 25923 at a $1 \%$ of Minimum Inhibition Concentration (KHM). RJ2 compound was yellow oily (3.1 mg). The RJ2 compound can inhibit Escherichia coli ATCC 25922 at a 1\% of Minimum Inhibition Concentration (MIC).

Kata Kunci:

bakteri simbion;

Bacillus sp.; aktivitas antibakteri; spon laut;

Haliclona fascigera.

ABSTRAK: Bacillus sp. 3 (A1) merupakan salah satu isolat bakteri simbion spon laut Haliclona fascigera asal Pulau Mandeh, Pesisir Selatan, Sumatra Barat yang dapat memproduksi senyawa antibakteri. Penelitian ini bertujuan untuk mengisolasi senyawa aktif sebagai antibakteri yang dihasilkan oleh Bacillus sp.3 (A1). Metoda yang digunakan yaitu kultivasi bakteri pada media Nutrient Broth menggunakan Inkubator Shaker dengan kecepatan 150 RPM pada suhu 37으 selama 48 jam dan isolasi senyawa antibakteri. Metode pemisahan senyawa dilakukan dengan metoda kromatografi kolom. Pengujian aktivitas antibakteri dlakukan dengan metoda difusi agar. Karakterisasi senyawa hasil isolasi dilakukan dengan menggunakan spektrofotometer UV dan spektrometer IR. Dari penelitian ini didapatkan dua senyawa RJ1 dan RJ2. Senyawa RJ1 berupa minyak berwarna kuning (2,8 mg). Senyawa RJ1 dapat menghambat bakteri uji Staphylococcus aureus ATCC 25923 pada Konsentrasi Hambat Minimum 1\%. Senyawa RJ2 berupa minyak berwarna kuning $(3,1 \mathrm{mg})$. Senyawa RJ2 dapat menghambat bakteri uji Escherichia coli ATCC 25922 pada konsentrasi hambat minimum 1\%.
\end{abstract}

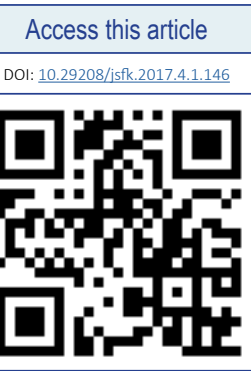

\section{PENDAHULUAN}

Penyakit infeksi telah menyebabkan kematian sebesar 13 juta orang di seluruh dunia setiap tahun, terutama di negara-negara yang sedang berkembang seperti Indonesia. Pemakaian antibakteri merupakan keharusan dalam penangulangan penyakit infeksi. Dalam beberapa tahun terakhir terdapat peningkatan angka resistensi terhadap antibiotika [1]. Terdapat sejumlah laporan bahwa bakteri Gram positif dan Gram negatif telah resisten terhadap antibiotika yang kerap kali digunakan. Beberapa bakteri yang dimaksud adalah Salmonella typhi [2], Bacillus licheniformis, Acinetobacter calcoaceticus [3], dan Staphylococcus epidermidis [4].

Fakta di atas menjelaskan bahwa perlunya penemuan senyawa antibakteri atau senyawa bioaktif baru yang berasal dari sumber daya alam di Indonesia. Indonesia dikenal sebagai negara bahari dengan luas $75 \%$ berupa lautan, 
memiliki kekayaan sumber daya hayati yang melimpah, antara lain ditemukan berbagai jenis spon. Beberapa jenis spon tersebut dilaporkan memiliki senyawa bioaktif yang dapat digunakan dalam bidang farmasi [5].

Spon laut diketahui menjadi tempat hidup beberapa jenis bakteri yang jumlahnya mencapai $40 \%$ dari biomassa spon. Simbiosis yang terjadi antara bakteri dengan spon laut menyebabkan invertebrata laut ini memiliki potensi antibakteri yang lebih besar dibandingkan dengan organisme darat dan laut lainnya [6].

Salah satu contoh senyawa aktif yang telah ditemukan dan dilaporkan dari genus Haliclona adalah haliclotriol A dan B (triterpen ketida), papuamine, dan haliclonadiamine A (alkaloid) yang memiliki aktivitas sebagai antimikroba [7]. Senyawa yang telah ditemukan dari spon Haliclona fascigera yaitu helianane yang merupakan golongan seskuiterpen [8]. Aktivitas antibakteri juga ditemukan pada hasil ekstraksi Haliclona fascigera dimana pada konsentrasi ekstrak metanol 5\% memperlihatkan aktivitas antibakteri dengan diameter hambat $14 \mathrm{~mm}$ terhadap E. coli dan 15 $\mathrm{mm}$ terhadap $S$. aureus, pada konsentrasi ekstrak methanol $3 \%$ diameter hambatnya $13 \mathrm{~mm}$ terhadap E. coli dan $S$. aureus, dan pada konsentrasi ekstrak metanol 1\% diameter hambatnya $11 \mathrm{~mm}$ terhadap E. coli dan S. aureus [9].

Terdapat 16 bakteri yang telah diisolasi dan 4 diantaranya memiliki aktivitas antibakteri pada penelitian Febrianto (2014). Salah satu bakteri yang memiliki akivitas adalah isolat bakteri A1. Ekstrak etil asetat bakteri A1 (Bacillus sp.3) memiliki aktivitas terhadap bakteri uji $S$. aureus dengan diameter hambat sebesar $10 \mathrm{~mm}, 12 \mathrm{~mm}$ dan $18 \mathrm{~mm}$ pada konsentrasi berturut-turut $0.5 \%, 1 \%$ dan $2 \%$ serta memiliki aktivitas terhadap bakteri uji E. coli dengan diameter hambat $8 \mathrm{~mm}, 9 \mathrm{~mm}$ dan 11 $\mathrm{mm}$ pada konsentrasi berturut-turut $0.5 \%, 1 \%$, dan $2 \%$ [10]. Penelitian ini merupakan penelitian lanjutan untuk mengisolasi dan karakterisasi awal senyawa antibakteri dari isolat Bacillus sp3. (A1), simbion dari Haliclona fascigera.

\section{METODE PENELITIAN}

\section{Bakteri dan Bahan}

Bahan yang digunakan dalam penelitian ini adalah adalah isolat bakteri Bacillus sp.3 (A1) simbion dari spon laut Haliclona fascigera yang diperoleh dari peneliti sebelumnya [10]. media pembenihan padat (Nutrient Agar) (Merck®), media pembenihan cair (Nutrient Broth) $\left(\right.$ Merck $\left.^{\circledR}\right)$, silika gel $60\left(\right.$ Merck $\left.^{\circledR}\right)$, antibiotik kloramfenikol 0.3\% $\left(\right.$ Sigma $\left.^{\circledR}\right)$, pelarut etil asetat, metanol, dan n-heksan.
Penentuan waktu kultivasi optimum isolat Bacillus sp.3 (A1)

Koloni bakteri yang telah diinkubasi pada media Nutrient Agar (NA) $\left(\right.$ Merck $\left.^{\circledR}\right)$, selama 24 jam pada suhu $37{ }^{\circ} \mathrm{C}$, diambil 1 ose dan dipindahkan kedalam $10 \mathrm{~mL}$ media Nutrient Broth (NB) $\left(\operatorname{Merck}^{\circledR}\right)$, dan dihomogenkan. Kemudian diinkubasi selama 24 jam suhu $37^{\circ} \mathrm{C}$ dengan kecepatan 150 RPM dan digunakan sebagai starter inoculum.

Starter inoculum bakteri sebanyak $10 \mathrm{~mL}$ kemudian dicukupkan menjadi $100 \mathrm{~mL}$ dengan media NB, dan dikultivasi dengan alat Incubator Shaker Series pada suhu $37^{\circ} \mathrm{C}$ dengan kecepatan $150 \mathrm{rpm}$ selama 96 jam. Setiap $0,24,30,48,72$, dan 96 jam waktu inkubasi, dilakukan pengukuran Optical Density (OD) media kutivasi dengan menggunakan spektrofotometer UV-VIS Pharmaspec 1700 (Shimadzu $^{\circledR}$ ), pada panjang gelombang $600 \mathrm{~nm}$. Data pengukuran tersebut digambarkan sebagai kurva pertumbuhan bakteri.

Kultivasi isolat Bacillus sp.3 (A1)

Kultivasi isolat Bacillus sp.3 (A1) dilakukan menggunakan media NB. Satu ose kultur bakteri dimasukkan ke dalam 54 labu Erlenmeyer ukuran $250 \mathrm{~mL}$ yang berisi $150 \mathrm{~mL}$ media NB dan diinkubasi dengan alat Incubator Shaker Series dengan kecepatan 150 RPM pada suhu $37^{\circ} \mathrm{C}$ selama 48 jam (waktu kultivasi optimum).

Ekstraksi senyawa metabolit sekunder isolat Bacillus sp.3 (A1)

Kultur Bacillus sp. 3 (A1) sebanyak 8 L dimaserasi menggunakan pelarut etil asetat perbandingan 1:1 dan disonikasi selama 10 menit. Ekstrak etil asetat dipisahkan dari media kultur menggunakan corong pisah dan disaring menggunakan kertas saring. Ekstrak organik yang didapat kemudian diuapkan pelarutnya dengan rotary evaporator $\left(\right.$ Buchi $\left.^{\circledR}\right)$.

\section{Isolasi dan pemurnian senyawa antibakteri}

Untuk menentukan eluen yang akan digunakan untuk kolom kromatografi maka dilakukan monitoring pola noda dengan plat Kromatografi Lapis Tipis (KLT) $\left(\operatorname{Merck}^{\circledR}\right)$, Hasil pemeriksaan dengan plat KLT menunjukkan pola penyebaran senyawa-senyawa yang baik menggunakan fasa gerak etil asetat : metanol (19:1) dengan penampak noda lampu UV254nm. Selanjutnya dilakukan isolasi senyawa antibakteri ekstrak etil asetat Bacillus sp.3 (A1) menggunakan kromatografi kolom dengan menggunakan fasa diam silica gel $60(0.2-0.5 \mathrm{~mm})$ dan fasa gerak etil asetat:metanol dengan perbandingan 19:1 secara isokratik. Hasil kromatografi kolom ditampung dengan vial ukuran 
$10 \mathrm{~mL}$ sebanyak 71 vial. Eluen tersebut dimonitor dengan KLT dan penampak noda lampu UV254 nm. Fraksi dengan pola noda yang sama kemudian digabung sehingga diperoleh 8 fraksi yaitu fraksi A (1-4), B (5-8), C (9-13), D (14-16), E (17-20), F (21-37), G (38-54) dan H (55-71). Selanjutnya dari 8 fraksi tersebut diuji aktivitas antibakteri dengan metoda difusi menggunakan $S$. aureus ATCC 25923 dan E. coli ATCC 25922. Dari hasil uji aktivitas antibakteri diketahui bahwa fraksi A dan B memiliki aktivitas antibakteri yang ditandai dengan adanya zona bening pada cawan petri.

\section{Uji aktivitas antibakteri}

Pengujian aktivitas antibakteri dilakukan dengan metode swab (bakteri uji digoreskan secara merata) kemudian kertas cakram steril yang telah ditetesi larutan fraksi senyawa yang didapatkan diletakkan di atas permukaan media NA yang sudah memadat. Inkubasi bakteri dilakukan pada suhu $37^{\circ} \mathrm{C}$ selama 24 jam. Zona bening yang muncul setelah diinkubasi diamati dan diukur diameternya. Sebagai kontrol negatif digunakan pelarut etil asetat dan sebagai kontrol positif digunakan antibiotik kloramfenikol 0,3\% $\left(\right.$ Sigma $\left.^{\circledR}\right)$.

\section{Karakterisasi senyawa hasil isolasi}

Karakterisasi senyawa hasil isolasi, meliputi pemeriksaan organoleptis, pemeriksaan kimia dan fisikokimia, kelarutan, kromatografi. Pemeriksaan fisikokimia meliputi analisis menggunakan spektrofotometer UV-VIS Pharmaspec $1700\left(\right.$ Shimadzu $\left.^{\circledR}\right)$ dan Spektrofotometer Fourtier Transform InfraRed (FTIR) Spectrum One (Perklin Elmer ${ }^{\circledR}$ ).

\section{HASIL DAN DISKUSI}

Spesies Bacillus merupakan bakteri gram positif aerob atau anaerob fakultatif berbentuk batang sporulasi yang tersebar luas di alam [11]. Hasil penelusuran literatur menunjukkan bahwa sejumlah bakteri dari spesies Bacillus seperti Bacillus subtilis, Bacillus firmus, Bacillus brevis, Bacillus licheniformis memiliki aktivitas antibakteri terhadap $S$. aureus. Sedangkan Bacillus cereus, Bacillus firmus dan Bacillus brevis diketahui memiliki aktivitas antibakteri terhadap E. coli [12].

Sebelum dilakukan proses isolasi senyawa antibakteri, dilakukan penentuan waktu kultivasi optimum Bacillus $s p .3$ (A1). Hal ini bertujuan untuk memperkirakan waktu kultivasi sehingga diperoleh jumlah metabolit sekunder yang maksimal. Nilai absorban yang paling besar menunjukkan jumlah bakteri pada media kultur lebih banyak akibat dari kekeruhan [13].

Berdasarkan kurva pertumbuhan bakteri Bacillus sp.3 (A1), waktu kultivasi optimum terjadi pada waktu 48 jam. Pada waktu 48 jam pertumbuhan bakteri tersebut, kultur bakteri Bacillus sp.3 (A1) menunjukkan nilai kekeruhan paling tinggi $(A b s=1,735)$ dibandingkan dengan waktu lainnya yaitu waktu ke- 0, 24, 48, 72, dan 96 jam.

Dari hasil kultivasi Bacillus sp.3 (A1) sebanyak \pm 8 L diperoleh ekstrak kental etil asetat sebanyak $457 \mathrm{mg}$. Pemisahan senyawa menggunakan kromatografi kolom dengan metode isokratik (perbandingan tetap yaitu etil asetat:metanol (19:1). Metoda isokratik ini digunakan apabila komponen-komponen kimia dalam suatu fraksi dapat memisah dengan baik yang diketahui dari pola noda pada KLT. Pemisahan senyawa menggunakan kromatografi kolom didapatkan 8 fraksi yaitu fraksi A $(58,4 \mathrm{mg})$, fraksi B

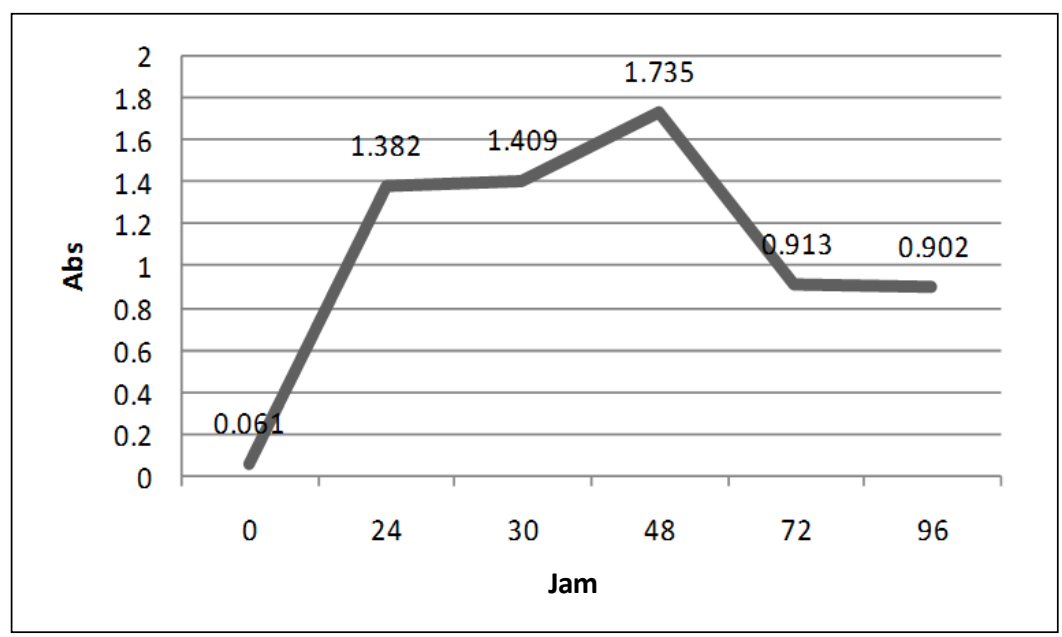

Gambar 1. Kurva optimasi waktu pertumbuhan Bacillus sp.3 (A1) 


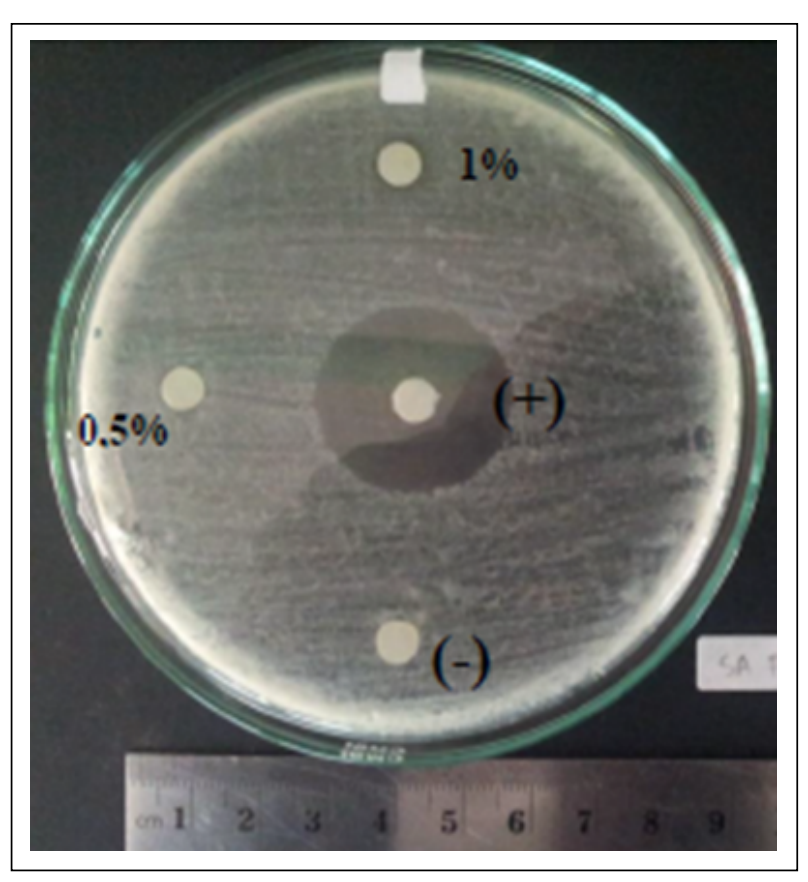

Gambar 2. Hasil uji aktivitas antibakteri senyawa RJ1 terhadap S. aureus ATCC 25923

Tabel 1. Diameter hambat senyawa RJ1

\begin{tabular}{|cc|}
\hline Konsentrasi & Diameter Hambat (mm) \\
\hline $1 \%$ & 7,5 \\
$0,5 \%$ & - \\
Kontrol (+) & 25 \\
Kontrol (-) & - \\
\hline
\end{tabular}

(59,5), fraksi C (116 mg), fraksi D (21,9 mg), fraksi E (20,4 $\mathrm{mg})$, fraksi $\mathrm{F}(53,3 \mathrm{mg})$, fraksi $\mathrm{G}(34,6 \mathrm{mg})$, dan fraksi $\mathrm{H}$ $(128,4 \mathrm{mg})$. Delapan fraksi tersebut dilakukan uji aktivitas antibakteri untuk mengetahui fraksi yang akan dilanjutkan dengan tahap isolasi. Dari hasil uji aktivitas antibakteri terhadap $S$. aureus dan E. coli menunjukkan bahwa fraksi A aktif terhadap $S$. aureus pada konsentrasi $1 \%$ dan fraksi B aktif terhadap S. aureus dan E. coli pada konsentrasi 1\%.

Hasil monitoring KLT fraksi A tidak memperlihatkan pemisahan yang baik, maka dilakukan proses kromatografi kolom dengan metode SGP (Step Gradient Polarity) dimana fasa gerak yang digunakan dimulai dari pelarut nonpolar kemudian kepolaran pelarut ditingkatkan secara bertahap, baik dengan pelarut tunggal atau kombinasi dua pelarut yang berbeda kepolarannya dengan perbandingan tertentu sesuai dengan tingkat kepolaran. Fraksi kolom tersebut ditampung dalam vial dan fraksi dengan noda yang sama digabung. Diperoleh 5 fraksi yaitu fraksi A1
(15,4 mg), A2 (2,8 mg), A3 (1,7 mg), A4 (5,9 mg), dan A5 $(11,4 \mathrm{mg})$. Hasil uji aktivitas antibakteri terhadap $S$. aureus pada konsentrasi $1 \%$ menunjukkan bahwa terdapat zona hambat di sekeliling cakram dari fraksi A1, A2, dan A3. Hasil monitoring dengan menggunakan KLT dari keenam fraksi, fraksi A2 telah memberikan 1 noda di bawah penampak noda sinar UV254 nm dan uap iodium.

Dari fraksi A2 diisolasi senyawa murni RJ1 dengan jumlah 2,8 $\mathrm{mg}$ yang mempunyai Rf 0,5 dengan fase gerak n-heksan : etil asetat 4:1. Berdasarkan hasil pengujian aktivitas diketahui bahwa senyawa RJ1 pada konsentrasi $1 \%$ memberikan diameter hambat 7,5 mm sedangkan pada konsentrasi $0.5 \%$ tidak adanya diameter hambat. Sehingga Konsentrasi Hambat Minimum (KHM) senyawa RJ1 terhadap $S$. aureus adalah $1 \%$.

Tahap isolasi selanjutnya dilakukan terhadap raksi B yang memperlihatkan aktivitas terhadap bakteri E. coli dan $S$. aureus. Hasil monitoring KLT dari fraksi B yang tidak memperlihatkan pemisahan yang baik, maka dilakukan proses kromatografi kolom dengan metode SGP

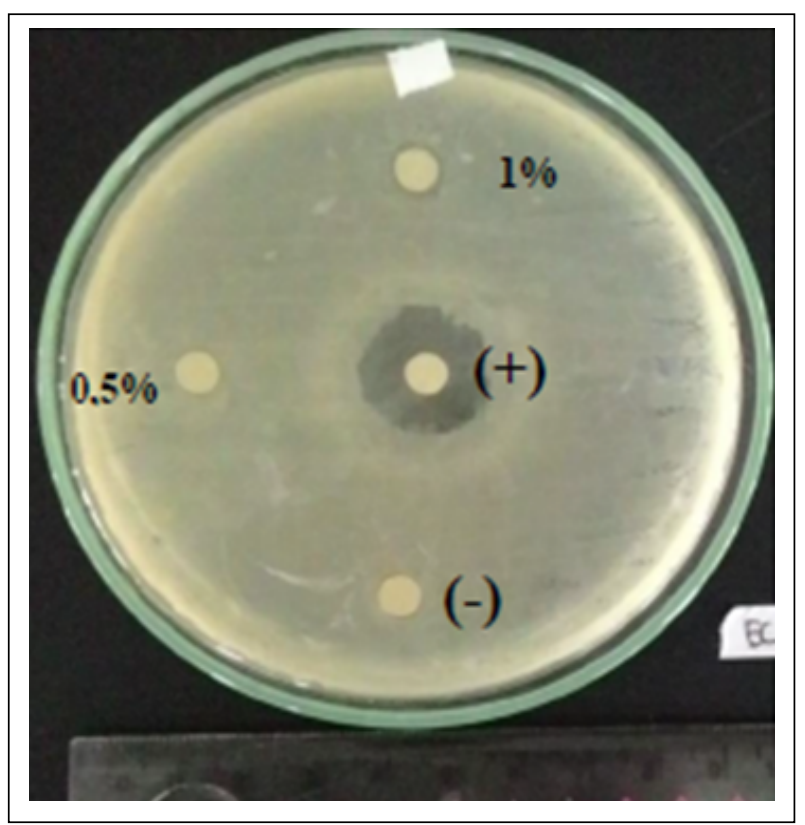

Gambar 3. Hasil uji aktivitas antibakteri senyawa RJ2 terhadap E. coli ATCC 25922

Tabel 2. Diameter hambat senyawa RJ1

\begin{tabular}{|cc|}
\hline Konsentrasi & Diameter Hambat $(\mathbf{m m})$ \\
\hline $1 \%$ & 8 \\
$0.5 \%$ & - \\
Kontrol (+) & 18 \\
Kontrol (-) & - \\
\hline
\end{tabular}


Tabel 3. Karakterisasi senyawa RJ1 dan RJ2

\begin{tabular}{|c|c|c|c|}
\hline No & Karakterisasi & Senyawa RJ1 & Senyawa RJ2 \\
\hline \multirow[t]{3}{*}{1} & Organoleptis & & \\
\hline & Bentuk & Minyak & Minyak \\
\hline & Warna & Kuning & Kuning \\
\hline 2 & Pemeriksaan Kelarutan & Larut dalam pelarut n-heksan & Larut dalam pelarut etil asetat. \\
\hline \multirow[t]{6}{*}{3} & Pemeriksaan Senyawa Kimia & & \\
\hline & Dragendorff & Tidak Bereaksi & Tidak Bereaksi \\
\hline & $\mathrm{FeCl} 3$ & Tidak Bereaksi & Tidak Bereaksi \\
\hline & Lieberman-Bourchard & Tidak Bereaksi & Tidak Bereaksi \\
\hline & $\mathrm{H}_{2} \mathrm{SO}_{4} 10 \%$ dalam $\mathrm{MeOH}$ & Tidak Bereaksi & Tidak Bereaksi \\
\hline & Uap Kristal lodium & Kuning-Jingga & Kuning-Jingga \\
\hline 4 & Pemeriksaan Kromatografi Lapis Tipis (KLT) & Fasa Gerak n-heksan:etil asetat $(4: 1) \mathrm{Rf}=0.5$ & Fasa Gerak n-heksan:etil asetat (2:3) $\mathrm{Rf}=0.5$ \\
\hline
\end{tabular}

(Step Gradient Polarity) dimulai dari pelarut n-heksan; perbandingan $\mathrm{n}$-heksan dan etil asetat hingga metanol. Fraksi kolom tersebut ditampung dalam vial dan fraksi dengan noda yang sama digabung. Diperoleh 7 fraksi yaitu fraksi B1 (10,5 mg), B2 (2,3 mg), B3 (4,3 mg), B4 (2,5 mg), B5 (2,7 mg), B6 (3,5 mg) dan B7 (3,9 mg). Selanjutnya dilakukan pengujian aktivitas antibakteri terhadap tujuh fraksi tersebut.

Hasil uji aktivitas antibakteri terhadap bakteri $S$. aureus dan E. coli menunjukkan bahwa semua fraksi tidak menunjukkan adanya aktivitas antibakteri terhadap bakteri S. aureus pada konsentrasi $1 \%$. Sedangkan hasil uji aktivitas terhadap bakteri E. coli dengan konsentrasi 1\%, fraksi yang menunjukkan aktivitas dan telah memberikan satu noda sinar UV254 nm dan uap iodium adalah fraksi B2.

Dari fraksi B2 diisolasi senyawa murni yaitu RJ2 dengan jumlah 3,1 mg yang mempunyai Rf 0,5 dengan fasa gerak n-heksan:etil asetat 2:3.

Senyawa RJ2 pada konsentrasi 1\% memberikan diameter hambat $8 \mathrm{~mm}$ dan pada konsentrasi $0,5 \%$ tidak adanya diameter hambat, sehingga Konsentrasi Hambat Minimum (KHM) fraksi RJ2 terhadap bakteri E. coli adalah $1 \%$.

Dari pemeriksaan kimia dilakukan dengan beberapa penampak noda pada plat KLT. Pemeriksaan kimia terhadap senyawa RJ1 dan RJ2 menggunakan pereaksi Dragendorff, $\mathrm{FeCl} 3$, Lieberman-Bourchard dan $\mathrm{H}_{2} \mathrm{SO}_{4}$ $10 \%$ dalam metanol tidak menimbulkan warna, sementara dengan pereaksi uap kristal iodium menghasilkan noda berwarna kuning-jingga.

Spektrum UV senyawa RJ1 dalam pelarut metanol memperlihatkan serapan maksimum pada panjang gelombang 252,00 nm (Abs=0,457). Dari data spektrum IR didapatkan fraksi RJ1 memperlihatkan adanya serapan pada bilangan gelombang 2923,39 - 2853,58 $\mathrm{cm}^{-1}$ yang diduga berasal dari rengang $\mathrm{C}-\mathrm{H}$ alifatis, absorpsi pada bilangan gelombang $1710,27 \mathrm{~cm}^{-1}$ yang merupakan karakteristik regang $\mathrm{C}-\mathrm{O}$, dan serapan pada bilangan gelombang $1463,52 \mathrm{~cm}^{-1}$ yang disebabkan regang -CH2 [14]. Senyawa RJ1 diduga adanya regang C-H alifatis dikarenakan tidak adanya bilangan gelombang 1300-1000 yang menunjukkan identitas regang $\mathrm{C}-\mathrm{H}$ aromatis serta pada serapan UV tidak memperlihatkan puncak yang jelas.

Spektrum UV senyawa RJ2 dalam pelarut metanol memperlihatkan serapan maksimum pada panjang gelombang 202,60 nm (Abs = 0,880). Dari data spektrum IR didapatkan fraksi RJ2 menunjukkan serapan kuat pada bilangan gelombang $3330,59 \mathrm{~cm}^{-1}$ yang diduga diberikan oleh gugus O-H. Serapan pada bilangan gelombang 2854,93-2925,69 $\mathrm{cm}^{-1}$ diduga disebabkan adanya regag $\mathrm{C}-\mathrm{H}$ alifatis, dan absorpsi pada bilangan gelombang $1714,58 \mathrm{~cm}^{-1}$ merupakan absorpsi karakteristik dari regang $\mathrm{C}=\mathrm{O}[14]$.

\section{KESIMPULAN}

Pada penelitian ini telah berhasil diisolasi senyawa RJ1 dan RJ2 yang yang dapat menghambat pertumbuhan bakteri S. aureus ATCC 25923 dan E. coli ATCC 25922 dari bakteri Bacillus sp.3 (A3) simbion spon laut Haliclona fascigera. 


\section{REFERENSI}

[1] Salni, S., Marisa, H., \& Mukti, R. W. (2011). Isolasi senyawa antibakteri dari daun jengkol (Pithecolobium lobatum benth) dan penentuan nilai KHM-nya. Jurnal Penelitian Sains, 14(1), 38-41.

[2] Chowta, M. N., \& Chowta, N. K. (2005). Study of clinical profile and antibiotic response in typhoid fever. Indian Journal of Medical Microbiology, 23(2), 125-127.

[3] Adimpong DB, Sørensen KI, Thorsen L, Stuer-Lauridsen B, Abdelgadir WS, Nielsen DS, Derkx PM, Jespersen L. (2012). Antimicrobial susceptibility of Bacillus strains isolated from primary starters for African traditional bread production and characterization of the bacitracin operon and bacitracin biosynthesis. Appl Environ Microbiol, 78(22), 7903-7914.

[4] Giacometti, A., Ghiselli, R., Cirioni, O., Mocchegiani, F., Orlando, F., Del Prete, M. S., ... \& Scalise, G. (2003). Prophylactic efficacy of linezolid alone or combined with levofloxacin and vancomycin in a rat subcutaneous pouch model of graft infection caused by Staphylococcus epidermidis with intermediate resistance to glycopeptides. Journal of Antimicrobial Chemotherapy, 52(4), 724726.

[5] Ahmad, S. A. (2004). Empat Puluh Tahun dalam Kimia Organik Bahan Alam Tumbuh-tumbuhan Tropika Indonesia. Rekoleksi dan Prospek. Bulletin of The Indonesian Society of Natural Products Chemistry, $4(2), 5-54$.

[6] Kanagasabhapathy, M., Sasaki, H., Nakajima, K., Nagata, K., \& Nagata, S. (2005). Inhibitory activities of surface associated bacteria isolated from the marine sponge Pseudoceratina purpurea. Microbes and Environments, 20(3), 178-185.
[7] Ely, R., Supriya, T., \& Naik, C. G. (2004). Antimicrobial activity of marine organisms collected off the coast of South East India. Journal of experimental marine biology and ecology, 309(1), 121-127.

[8] Harrison, B., \& Crews, P. (1997). The structure and probable biogenesis of Helianane, a heterocyclic sesquiterpene, from the Indo-Pacific sponge Haliclona fascigera. The Journal of Organic Chemistry, 62(8), 2646-2648.

[9] Nining. (2009). Isolasi dan Uji Aktivitas Senyawa Antibakteri dari Spon Laut Haliclona fascigera (Skripsi). Fakultas Farmasi Universitas Andalas.

[10] Febrianto, R. E., (2014). Penapisan Aktivitas Antimikroba Bakteri Endofit dari Spon Laut Haliclona fascigera Asal Perairan Pulau Mandeh Pesisir Selatan Sumatra Barat (Skripsi). Fakultas Farmasi Universitas Andalas.

[11] Graumann, P. (Ed) (2007). Bacillus: Cellular and Molecular Biology, 1st Ed., Caister Academic Press.

[12] Kuta, F. A., Nimzing, L., \& Orka'a, P. Y. (2009). Screening of Bacillus species with potentials of antibiotics production. Applied Medical Informatics, 24(1,2), 42-46.

[13] Radji, M. (2011). Buku Ajar Mikrobiologi Panduan Mahasiswa Farmasi dan Kedokteran. Jakarta: EGC.

[14] Silverstein, R.M.,Bassler, G.C., \& Morill, T.C. (1981). Spectrometric Identification of Organic Compounds, $4^{\text {th }}$ Ed., Wiley. Copyright @ 2017 The author(s). You are free to share (copy and redistribute the material in any medium or format) and adapt (remix, transform, and build upon the material for any purpose, even commercially) under the following terms: Attribution - You must give appropriate credit, provide a link to the license, and indicate changform, or build upon the material, you must distribute your contributions under the same license as the original (https://creativecommons. org/licenses/by-sa/4.0/)
transfor 